Матеріали науково-практично конференці з участю міжнародних спеціалістів «Актуальні питання діагностики, лікування, раціонально фармакотерапі, диспансеризаці та реабілітаці в практиці сімейного лікаря»

\title{
ЕФЕКТИВНІСТЬ ЗАСТОСУВАННЯ НЕКСІУМУ У ХВОРИХ НА БРОНХІАЛЬНУ АСТМУ В ПОЕДНАННІ 3 ГЕРХ
}

\author{
ФЛ. В. Глушко, Н. Р. Матковська, Л. В. Скрипник \\ ДВНЗ «Івано-Франківський національний медичний університет», м. Івано-Франківськ
}

Мета. Виявити поширеність гастроезофагеального рефлюксу (ГЕР) у хворих на бронхіальну астму (БА), вплив антисекреторного лікування на перебіг БА.

Матеріал та методи. Обстежено 115 хворих на БА середнього ступеня тяжкості $(64,3 \%$ жінок та $35,7 \%$ чоловіків, середній вік становив $((63,8 \pm 7,5)$ р.), яким проведено фіброезофагогастроскопію (ФЕГС) та ультразвукове контрастне дослідження стравоходу (УЗҚД). ГЕРХ виявлено у 64 (55,7\%) осіб, яким призначено т. Нексіуму у дозі 40 мг 1 р. на день впродовж 2 тижнів.

Результати. Клінічно ГЕРХ проявлявся печією у 99 (86,1\%) пацієнтів. Згідно з УЗКД, про наявність ГЕР свідчило подовження часу розширення абдомінального відділу стравоходу протягом 9 хв від початку УЗКД та збільшення діаметра стравоходу більше ніж на $(0,35 \pm 0,06)$ см на 3 -й хв. При
ФЕГС виявлено грижу стравохідного отвору діафрагми (КСОД) - у 42 (36,5\%) осіб, недостатність кардіального відділу діафрагми - у $35(30,4 \%)$, х поєднання - у 24 (20,9\%), рефлюкс-езофагіт - у 23 (20\%). За даними УЗКД, ГЕР підтверджений у $67(58,3 \%)$ хворих, КСОД - у 5 (4,3\%), х поєднання - у 41 (35,7 \%). Після призначення т. Нексіуму зменшилися печія, прояви ГЕР за даними УЗКД і покращився клінічний перебіг БА: зменшилась кількість нападів задухи та потреба у застосуванні бронходилататорів, збільшилися об'єм форсованого видиху за 1 хв у 52 (45,2\%) пацієнтів і життєва ємність легень у $55(47,8 \%)$ пацієнтів.

Висновки. Поєднання ГЕРХ та БА спостерігається у 55,7 \% хворих. Комплексне лікування із застосуванням т. Нексіуму значно покращує перебіг захворювання та дозволяє зменшити тривалість базового лікування БА. 